\title{
Pengajaran fisika dengan pagelaran wayang beber
}

\author{
Rachmad Resmiyanto \\ Program Studi Pendidikan Fisika, UIN Sunan Kalijaga \\ J1. Marsda Adisucipto Yogyakarta 5528I \\ Surat-e: rachmadresmi@gmail.com
}

Pengajaran fisika biasanya dilakukan dengan ceramah. Pada pengajaran ini, dosen berdiri di kelas dan menjelaskan materi fisika dengan bantuan tayangan presentasi atau papan tulis. Sesekali dosen berinteraksi dengan mahasiswa melalui pertanyaan-pertanyaan, baik yang dilontarkan oleh dosen ke mahasiswa atau dari mahasiswa ke dosen. Pengajaran fisika dengan cara yang berbeda dapat dilakukan dengan pagelaran wayang beber dengan bantuan slide Prezi.

Physics learning usually taught verbally. Lecturer stands in front of the class and explain the physics material through slide presentation or white board. Occasionally interaction occurred by questions, both were raised by lecturer to students or students to lecturer. Physics can be taught in a different way such as Wayang (puppets) Beber show with Prezi slides.

Kata kunci: pengajaran fisika, wayang beber, slide prezi

\section{Pendahuluan}

Sebagai bangunan ilmu, fisika dapat dibagi menjadi 6 bidang utama yaitu mekanika klasik, relativitas, termodinamika, elektromagnetisme, optika dan mekanika kuantum.

Selama ini dosen memberikan kuliah Fisika di kelas dengan ceramah. Pada pengajaran ini, dosen berdiri di kelas dan menjelaskan materi fisika dengan bantuan papn tulis atau tayangan presentasi (MS Power Point). Sesekali dosen berinteraksi dengan mahasiswa melalui pertanyaanpertanyaan, baik yang dilontarkan oleh dosen ke mahasiswa atau dari mahasiswa ke dosen.

Tayangan presentasi yang dibuat dengan Power Point memiliki ciri terdiri dari banyak slide dengan tiap-tiap slide menyajikan pokok pikiran tertentu. Bahkan, satu pokok pikiran kadang harus disajikan dalam beberapa slide.

Slide-slide tersebut ketika disajikan di layar harus disajikan satu slide demi satu slide. Power Point tidak memiliki keunggulan fitur untuk dapat menyajikan tayangan keseluruhan gagasan pada seluruh slide dalam sekali tayang. Dengan demikian, sangat dimungkinkan terjadi keterputusan ide dalam tayangan presentasi antar halaman slide.

Pengajaran yang dilakukan dosen di kelas sebenarnya mirip dengan pengajaran yang dilakukan seorang dalang pada sebuah pagelaran wayang. Perbedaan utamanya mungkin pada sifat jalur komunikasi dosen-mahasiswa yang bisa berinteraksi sedangkan seorang dalang biasanya tidak membuka jalur komunikasi dengan penontonnya. Dari beberapa ragam pagelaran wayang, ada satu pagelaran wayang yang menggunakan semacam tayangan presentasi seperti tayangan presentasi dosen. Pagelaran wayang tersebut ialah pagelaran wayang beber.

\section{Kajian Pustaka}

\section{Wayang Beber}

Wayang adalah salah satu seni budaya Indonesia yang paling populer di Indonesia apabila dibandingkan dengan karya seni budaya lainnya. Kesenian wayang berkembang terus dari masa ke masa. Wayang merupakan salah satu kesenian yang mudah sebagai media penerangan, dakwah, pendidikan, pemahaman filsafat, hiburan dan bahkan kritik sosial.

Salah satu ragam wayang ialah wayang beber. Pustakapustaka yang membahas tentang wayang beber sangat sedikit. Ini disebabkan wayang beber merupakan jenis wayang yang langka. Wayang beber tidak sepopuler wayang kulit atau wayang golek.

Ensiklopedi Terbuka Wikipedia ${ }^{[1]}$ memberikan deskripsi tentang wayang beber sebagai berikut,

Wayang beber adalah seni wayang yang muncul dan berkembang di Jawa pada masa pra Islam dan masih berkembang di daerah daerah tertentu di Pulau Jawa. Dinamakan wayang beber karena berupa lembaran lembaran (beberan) yang 
dibentuk menjadi tokoh tokoh dalam cerita wayang baik Mahabharata maupun Ramayana.

Wayang beber muncul dan berkembang di Pulau Jawa pada masa kerajaan Majapahit. Gambar-gambar tokoh pewayangan dilukiskan pada selembar kain atau kertas, kemudian disusun adegan demi adegan berurutan sesuai dengan urutan cerita. Gambar-gambar ini dimainkan dengan cara dibeber. Saat ini hanya beberapa kalangan di Dusun Gelaran, Desa Bejiharjo, Karangmojo Gunung Kidul, yang masih menyimpan dan memainkan wayang beber ini.

Konon oleh para Wali di antaranya adalah Sunan Kalijaga wayang beber ini dimodifikasi bentuk menjadi wayang kulit dengan bentuk bentuk yang bersifat ornamen yang dikenal sekarang, karena ajaran Islam mengharamkan bentuk gambar makhluk hidup (manusia, hewan) maupun patung serta menambahkan Pusaka Hyang Kalimusada. Wayang hasil modifikasi para wali inilah yang digunakan untuk menyebarkan ajaran Islam dan yang kita kenal sekarang.

Salah satu Wayang Beber tua ditemukan di Daerah Pacitan, Donorojo, wayang ini dipegang oleh seseorang yang secara turun-temurun dipercaya memeliharanya dan tidak akan dipegang oleh orang dari keturunan yang berbeda karena mereka percaya bahwa itu sebuah amanat luhur yang harus dipelihara. Selain di Pacitan juga sampai sekarang masih tersimpan dengan baik dan masing dimainkan ada di Dusun Gelaran Desa Bejiharjo, Karangmojo Gunungkidul.

Menurut Kitab Sastro Mirudo, Wayang Beber dibuat pada tahun 1283, dengan Condro Sengkolo, Gunaning Bujonggo Nembah Ing Dewo (1283), Kemudian dilanjutkan oleh Putra Prabu Bhre Wijaya, Raden Sungging Prabangkara, dalam pembuatan wayang beber. Wayang Beber juga memuat banyak cerita Panji, yakni Kisah Cinta Panji Asmoro Bangun yang merajut cintanya dengan Dewi Sekartaji Putri Jenggolo.”

Laman pacitanisti.wordpress.com menuliskan bagaimana pagelaran wayang beber dipentaskan ${ }^{[2]}$.

"... Wayang Beber dapat dimainkan dengan cara dibuka satu per satu atau digelar/dibeber.

Satu gulungan berisi 4 adegan, sehingga ketika adegan pertama diperlihatkan maka adegan ketiga sampai keempat masih dalam posisi tergulung. Kemudian jika berpindah dari gulungan satu kegulungan selanjutnya, maka pasak di sebelah kanan dalang dilepas terlebih dahulu, kemudian pasak gulungan yang baru dipasang, selanjutnya membuka gulungan baru sambil menutup gulungan sebelumnya, dan terakhir memasang pasak pada tempat penyimpanan Wayang Beber tersebut.

Dalang menceritakan cerita yang terlukis di gulungan Wayang Beber tersebut dengan menggunakan Bahasa Jawa dengan posisi membelakangi Wayang Beber, atau menghadap penonton.

Dilihat dari bentuk pertunjukannya, wayang beber termasuk pentas seni tradisional sederhana yang hanya terdapat beberapa unsur yang menjadi pendukungnya, yakni:

I) Seperangkat wayang yang terdiri dari enam gulungan dan masing-masing gulungan terdiri dari empat adegan.

2) Seperangkat gamelan yang terdiri dari gong, kenong laras slendro, kendang, dan rebab.

3) Niyaga, terdiri dari empat orang.

4) Lakon atau cerita wayang beber yang hanya memiliki satu siklus cerita saja.

Urutan pertunjukan :

I) Dalang membakar kemenyan, kemudian membuka kotak dan mengambil tiap gulungan menurut kronologi cerita.

2) Dalang membeberkan gulungan gulungannya pertama dan seterusnya, dengan membelakangi penonton.

3) Dalang mulai menuturkan janturan (narasi).

4) Setelah janturan, mulailah suluk (Lagu penggambaran) yang amat berbeda dengan umumnya suluk wayang purwa.

5) Setelah suluk, dimulailah pocapan berdasarkan gambar wayang yang tengah dibeberkan. Begitu pula seterusnya sampai seluruh gulungan habis dibeberkan dan dikisahkan.”

Contoh pagelaran wayang beber dapat dilihat pada laman Youtube ini dengan dalang muda Rudi Prasetya http://www.youtube.com/watch?v=Rsn_w0JAg6 $6 \mathrm{I}^{[3]}$. Lakon yang dibeber ialah Joko Kembang Kuning.

\section{Dalang}

Menurut Ensiklopedi Wayang Indonesia sebagaimana dikutip oleh laman hadisukirno.co.id ${ }^{[4]}$, dalang adalah pemimpin, pengarah, sutradara dan dirijen dari suatu pertunjukkan wayang. Kecuali pertunjukkan Wayang Orang dan Wayang Topeng, Dalang harus memainkan seluruh gerak peraga tokoh wayang yang dimainkannya. Ia juga memberi pengarahan pada para penabuh gamelan, pesinden dan wiraswara. Pengarahan itu dilakukan dengan berbagai isyarat yang dipahami oleh anak buahnya.

Lebih lanjut, laman tersebut juga menyatakan bahwa,

"Seorang dalang harus hafal banyak cerita wayang, memahami silsilah tokoh-tokoh wayang, dan tahu tentang filsafat cerita yang terkandung di dalamnya. Ia harus pandai memaparkan cerita itu secara tertib, berurut, lancar dan memikat. Ia pun harus mahir memainkan dan memperagakan 
tokoh-tokoh wayang yang dimainkan dan paham betul akan karakter tokoh wayang itu.

Selain itu ia masih dituntut kepandaian memainkan warna suaranya, sehingga suara tokoh yang diperankan menyimpulkan pula karakter tokoh wayang itu. Dalang yang baik juga harus memiliki kharisma, punya greget, dapat menguasai dan mengendalikan emosi penontonnya."

Seorang dalang harus memiliki beberapa kemampuan, yaitu

I) Parama Sastra, seorang dalang harus kaya akan perbendaharaan kata, ahli dalam tata bahasa, terutama bahasa lisan.

2) Mardi Basa, Dalang yang baik harus pandai memainkan atau mengolah kata-kata yang digunakan, sehingga penceritaannya lebih meikat perhatian penonton, lebih dapat membawakan suasana cerita.

3) Mardawa lagu, artinya dalang harus menguasai berbagai tembang, gending dan seni karawitan.

4) Hawicarita, Dalang harus seorang yang mempunyai kemampuan bercerita, kemahiran untuk membawakan cerita secara runtut dan memikat. Tidak ada bagian cerita yang terlupa.

5) Nawung Krida, dalang harus mengerti dasar-dasar ilmu psikologi, memahami karakter semua tokoh wayang dan kaitannya dengan karakter manusia.

\section{Hasil Penelitian dan Pembahasan}

\section{Pemilihan Tokoh}

Pengajaran fisika dengan ceramah dapat dikatakan tanpa memerlukan persiapan khusus yang unik. Ini berbeda dengan pengajaran fisika dengan pagelaran wayang beber yang memerlukan beberapa kesiapan di awal yaitu, pemilihan tokoh cerita, pembuatan tayangan beber, penyusunan alur cerita.

Dalam pemilihan tokoh, sebaiknya dipilih tokoh yang memudahkan alur cerita terkait dengan materi. Jumlah tokoh yang terlibat dalam alur cerita sebaiknya tidak terlalu banyak. Tokoh wayang yang fleksibel untuk pengajaran fisika (dan pengajaran sains secara umum) ialah Punokawan, pendamping ksatria Pandawa, yaitu Semar, Gareng, Petruk dan Bagong.

Jika dikehendaki tokoh wayang yang lain juga bisa, misalnya Puntodewa dan Bima. Akan tetapi, pemilihan seperti ini akan menjadikan alur cerita fisika menjadi kurang fleksibel. Oleh karena itu, menurut pengalaman penulis, tokoh yang sangat fleksibel ialah punokawan.

Berdasarkan pengalaman-pengalaman pertunjukan wayang punokawan sering terlibat dalam percakapan yang bebas dari pakem-pakem tertentu. Tentu saja ini berbeda jika tokoh yang dipilih ialah para ksatria. Suasana percakapan ksatria harus mengikuti pakem-pakem tuturan ksatria.

\section{Penyusunan Cerita}

Pengajaran fisika dengan ceramah dapat dikatakan tanpa memerlukan persiapan khusus yang unik. Ini berbeda dengan pengajaran fisika dengan pagelaran wayang beber yang memerlukan beberapa kesiapan di awal yaitu, pemilihan tokoh

Wayang beber asli menggunakan satu layar besar berisi 4 adegan cerita. Seluruh tokoh yang terlibat, peristiwa yang dialami tokoh dan tempat/latar terjadinya peristiwa dilukis dalam satu layar sehingga menerbitkan kesan bertumpuk-tumpuk. Ini dapat dilihat pada gambar I.

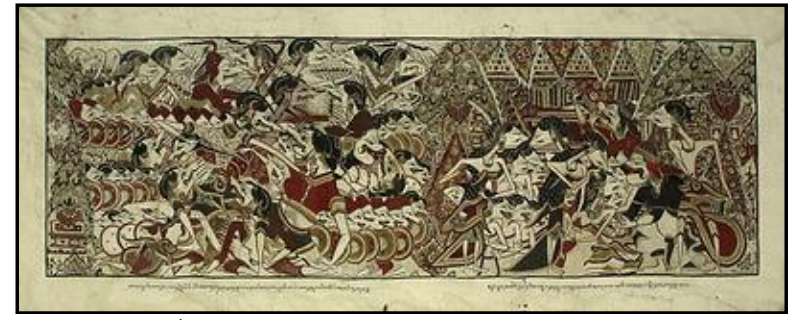

Gambar I. Wayang beber asli (Wikipedia, 2016)

Untuk membuat layar/beberan seperti wayang beber secara digital dapat digunakan software presentasi Prezi ${ }^{[5]}$. Seluruh tokoh punakawan yang sudah dipilih, materi fisika yang akan diceritakan dan suasana percakapan dapat disajikan secara utuh dalam satu layar. Seluruh adegan fisika (bab besaran dan satuan) disajikan dalam satu layar utuh. Punakawan dan materi-materi fisika ditempatkan pada layar yang sama. Ini dapat dilihat pada gambar 2 .

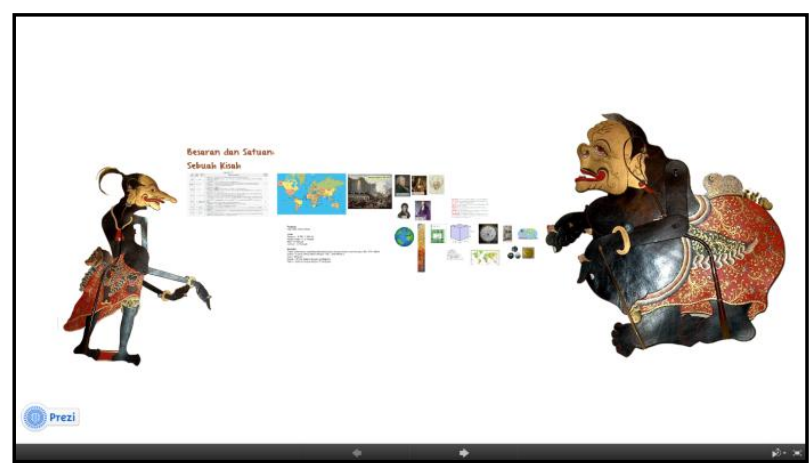

Gambar 2. Tampilan wayang beber fisika dengan tokoh Semar dan Petruk

Pada wayang beber fisika, tokoh yang dipilih ialah Semar dan Petruk. Keduanya ditampilkan dalam posisi berhadapan sehingga suasana percakapan dapat terbangun. Materi-materi fisika, baik teks maupun gambar, diletakkan diantara kedua tokoh. Ini untuk mengesankankan bahwa materi-materi fisika tersebut merupakan topik percakapan kedua tokoh. 


\section{Penyajian Wayang Beber Fisika}

Dalam wayang beber asli, ketika dalang sedang bertutur, maka ia akan menunjuk-nunjuk tokoh yang sedang berbicara dengan bilah. Penampilan ini dapat dilihat pada url http://www.youtube.com/watch?v=Rsn_w0JAg6I.

Penampilan tersebut dapat ditiru dengan mudah dengan software presentasi Prezi. Prezi tidak menganut logika linear seperti software-software presentasi lainnya. Prezi memudahkan presenter (dosen) untuk mondar-mandir dalam presentasi. Dengan prezi, dosen hanya perlu mengarahkan kursor (pointer) ke arah tokoh punakawan yang sedang berbicara atau materi fisika yang sedang dipercakapkan. Penampilan-penampilan antara tokoh dan materi dapat ditayangkan secara bolak-balik dengan cara cukup menggerakkan kursor. Dan jika hendak menampilkan tayangan adegan utuh, dosen juga hanya perlu menggeser kursor. Dengan demikian, tayangan adegan demi adegan dalam wayang beber fisika nyaris sama dengan wayang beber asli. Ini ditunjukkan pada gambar 3 dan 4 .

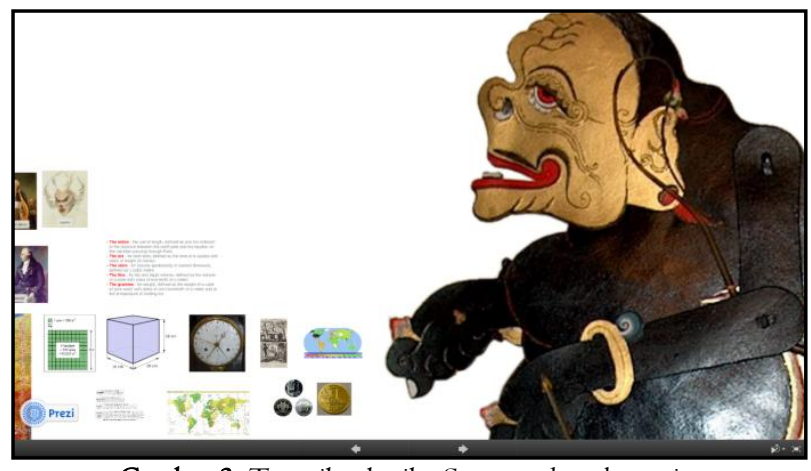

Gambar 3. Tampilan ketika Semar sedang bercerita

\section{Kelebihan dan Kekurangan Wayang Beber Fisika}

Pengajaran dengan menggunakan teknik ini membutuhkan keterampilan bersastra yang baik. Ini dibutuhkan terutama ketika sedang mencandra suasana dan tempat. Selain itu, keruntutan dalam berutur dan pengolahan emosi mahasiswa juga amat diperlukan sehingga mahasiswa tidak jenuh selama pagelaran berlangsung.

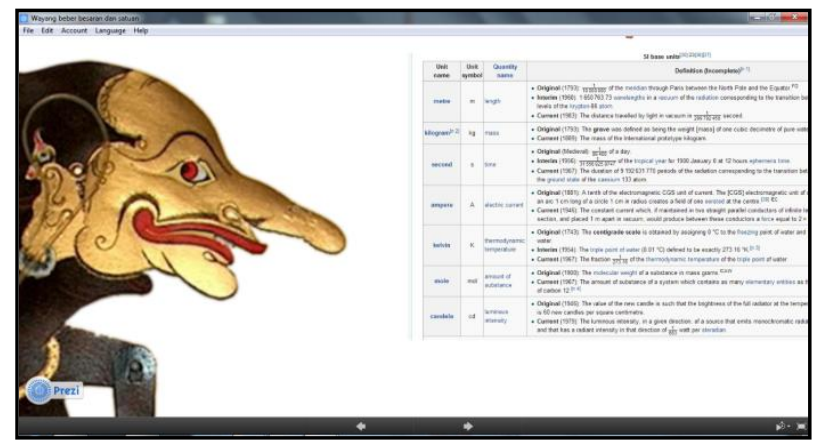

\section{Gambar 4. Tampilan ketika Petruk sedang bercerita}

Beberapa kesulitan yang penulis temukan di lapangan ialah kendala bahasa Indonesia. Pagelaran wayang umumnya diselenggarakan dengan menggunakan bahasa Jawa sehingga pencandraan suasana, penyampaian materi, guyonan dapat berjalan lancar. Ini berbeda ketika diselenggarakan sepenuhnya dalam bahasa Indonesia. Banyak keterbatasan yang dimiliki oleh bahasa Indonesia dalam penyelenggaraan pagelaran wayang beber fisika.

Pagelaran wayang beber fisika menuntut dosen untuk terus melakukan dialog antar tokoh selama pengajaran berlangsung. Ini berbeda dengan ceramah yang alur ceritanya hanya maju searah. Dalam sejarah, penyampaian materi-materi fisika secara dialogis pernah dilakukan oleh Galileo Galilei melalui bukunya yang sangat terkenal, Dialogue Concerning the Two Chief World Systems tahun I632 M. Penyampaian materi fisika dalam bentuk dialog dapat mewakili pertanyaan-pertanyaan yang sering muncul dalam benak mahasiswa tetapi tidak tersampaikan kepada dosen.

\section{Kesimpulan}

Pagelaran wayang beber dapat digunakan sebagai alternatif dalam mengajar pada mata kuliah fisika. Wayang beber fisika secara digital dapat diwujudkan dengan menggunakan software Prezi. Tokoh wayang yang mudah dijadikan tokoh cerita ialah punakawan. Pagelaran wayang beber fisika membutuhkan keterampilan bertutur yang lebih jika dibandingkan dengan pengajaran ceramah.

Penulis menyarankan perlunya dilakukan penelitian lanjutan mengenai pengaruh dan keefektifan pengajaran fisika dengan wayang beber ini.

\section{Kepustakaan}

[I] http://id.wikipedia.org

[2] http://pacitanisti.wordpress.com

[3] http://www.youtube.com/watch?v=Rsn_w0]Ag6I

[4] http://hadisukirno.co.id

[5] http://prezi.com 